\title{
ATTRACTIVENESS OF AREA AS THE SIGNIFICANT DETERMINANT OF LOCALIZATION OF RETAIL
}

\section{ATRAKTIVITA ÚZEMIA AKO VÝZNAMNÝ FAKTOR LOKALIZÁCIE MALOOBCHODU}

\section{ING. ERIKA DUDÁŠ PAJERSKÁ}

\author{
Katedra marketingu a obchodu $\mid$ Department of Marketing and Business \\ Podnikovohospodárska fakulta so sídlom v Košiciach Faculty of Business Economy with seat in Košice \\ Ekonomická univerzita v Bratislave University of Economics in Bratislava \\ $\triangle$ Tajovského 13, 04130 Košice, Slovak Republic \\ E-mail: erika.pajerska@euba.sk
}

\begin{abstract}
Annotation
Retail is currently defined as an important part of the economy with a significant impact on the level of gross domestic product. Due to this fact, many areas are trying to attract the interest of managers retailers to localize their business units directly in their ground. This new phenomenon attractiveness of economy is emerging, which also affects the retail location. This article aims to introduce the phenomenon of area attractions, factors and values as well as it focuses more detail on those that affect the localization of retail units. Paper orients its views on the subject divided according to whether we perceive attractiveness in terms of "old" industrial economy or in terms of a "new" creative economy. To achieve the target, article uses empirical methods of inquiry which are based on actual data and created experimental "ideal" region. The main contribution of the work lies also in the comparative analysis of views of "old" and "new" economy to the attractiveness of the territory following the localization of retail units and paper examines the relationship between these two variables. By the summary, report is trying to conclude by its findings, for this sphere of research.
\end{abstract}

\section{Key words}

attractiveness, area, retail, localization, industrial economy, creative economy

\begin{abstract}
Anotácia
Maloobchod je v súčasnej dobe definovaný ako dôležitá súčast’ ekonomiky s výrazným dopadom na úroveň hrubého domáceho produktu. Vzhl'adom k tejto skutočnosti, mnohé územia sa snažia prilákat' záujem manažérov maloobchodov, aby umiestnili svoje obchodné jednotky priamo v danom územi. Tým sa vynára nový fenomén atraktivity územia, ktorý ovplyvňuje aj lokalizáciu maloobchodu. Tento príspevok si kladie za ciel' predstavit' fenomén atraktivity územia, faktory či hodnoty, ktoré ho stanovujú, pričom sa detailnejšie orientuje na tie, ktoré majú vplyv na lokalizáciu maloobchodných jednotiek. Článok pritom svoj pohl'ad na túto problematiku rozdeluje podl'a toho, či atraktivitu vnímame v podmienkach „starej“ industriálnej ekonomiky alebo vintenciách „novej" kreatívnej ekonomiky. Pre dosiahnutie ciel’a článok využiva metódy empirického skúmania, ktoré sa opierajú o skutočné údaje a vytvorený experimentálny “ideálny” región. Hlavný prínos práce spočiva d’alej vo využití porovnávacej analýzy pohl'adov „starej“ a „novej“ ekonomiky na atraktivitu územia $v$ nadväznosti na lokalizáciu maloobchodu a skúma vztah medzi týmito dvoma veličinami. V zhrnutí sa článok prostredníctvom jeho zisteni snaži vyslovit’ závery pre túto sféru výskumu.
\end{abstract}

\section{Kl’účové slová}

atraktivita, územie, maloobchod, lokalizácia, industriálna ekonomika, kreatívna ekonomika

JEL classification: R12, D21, L22 
Introduction

Retail area with its wide range of activities, which are included under the term "retail", it recently gains more and more interest in views of economists as well as other professionals. Nowadays time force us to focus more emphasis on the impact of the external environment on the internal environment of the firm and that the retail managers' decisions about where to place their unit become significant for the overall operation of retail on the market.

This fact is also aware of the other party - the territory that is trying to create the best conditions for the functioning of retail. So a certain "competition" between the territories is specified by exploiting the phenomenon of attraction area which acts as a key factor influencing the thinking of managers of retail businesses in deciding about the location of its units.

\section{Objective and methods}

The paper focuses on the above-mentioned phenomena of our time as well as the perception of these "symptoms" which are divided according to whether we are talking about the "old" industrial or "new" creative economy. For achieving this targets, article uses empirical methods of inquiry based on actual data and created experimental "ideal" region with subsequent use of comparative analysis.

\section{Attractiveness of the area}

In examining the phenomenon of attractiveness of the area is necessary to aware these two facts:

- First, each area operates in a specific region of defined country and so it is necessary to realize the essence of attractiveness of the territory. Possible example is through an understanding of existing benefits, value orientation and traditions by which are is characterized.

- Second, in analyses of the attractiveness of the territory we take into account the fact that what may be seen as something attractive by one, can be taken as a factor which is just dissuasive for others.

These two paragraphs describe the immense power of the phenomenon of attractiveness of the territory but on the other hand, describe also potential threats. The attractiveness of cities has become an important topic for policy makers and city planners in order to enhance their competitiveness through a flexible, adaptable and diverse local economic structure by which the city is better positioned in global competition. At the same time, the attractiveness of cities does not have a clear definition in academic researches. (Ezmale and Litavniece 2011, 21). This represents a very broad scope and the focus of this paper is to reflect consideration of these points in the overall analysis of the issues in this article.

Understanding the attractiveness of the area is useful by other criteria. The current global time offers us new and new trends that should be taken by the economies if they want to keep pace with developed countries and do not abhorred. However, not all economies can do that and therefore there is unequal development of economies and different perceptions of these countries. One of the reasons is for example that the economies are equipped with the factors of growth in one particular moment and also particular growth factors are used in different amount and with different intensity (Tvrdoň, Hamalová, Žárska 1997, 33-34). It could be said that analyzing of diversity between areas could be seen from wide range of positions ${ }^{1}$.

\footnotetext{
${ }^{1}$ For more details, see following papers:

- Bracalente, B. - Perugini, C. (2010). The components of regional disparities in Europe,

- Bosker, M. (2008). The spatial evolution of regional GDP disparities in the „old“ and the „new“ Europe.

- Drejerska, N. (2012). Looking for fruther determinants of Regional Development.

- Geppert, K. - Stephan, A. (2007). Regional disparities in the European Union.

- Goshin, Z. - Danciu, A. - Gruiescu, M. (2007). Regional disparities of Economic Growth in the Enlarged EU.
} 
One of such trends - which was also selected for the purposes of this paper - is a sign of creative economy. Economies that are registering this trend but still did not come on this wave - they are operating under conditions of industrial economy. It results in new view on global economy - this was also realized by Krugman who initiated - by the seminar contribution - new theory that explains the emergence of heterogeneous economic space - new economic geography (Niebuhr 2006, 313). Due to these facts, it has also influence on the perception of attractiveness of area.

\section{Environment of "old" economy}

The term "old" economy for the purposes of this paper characterize the economy that structure of the sector still shows a first place for industrial activities. Such economy can indeed beginning of realizing of the potential of the creative sector, but does not yet make suitable environment for adequate application of potential of this sector. In other words, regional development might be due to variability in the industry mix across the sample regions, which depends, in theory, on some kind of comparative advantage or historical circumstances (Ezcurra and Pascual 2007, 5).

Values and traditions of these economies directly determine the perception of the attractiveness of the territory where as the main element is defined comparative benefits that territory can bring for a company that chooses to act in it. Between factors for increasing the attractiveness of the territory can be classified such items as advanced transportation equipment, optimal demographic ${ }^{2}$ and educational structure of population, income situation of population, position and distance of the territory or other barriers of the market which is limited to the territory. From the above mentioned facts follows that these factors are related to the area. They are (in some cases more, in others less) conditional to historical, social and political development of the area. They are often referred as so-called hard factors because they are limited exactly in the same boundaries which are reigning by government lines operating on the territory or in the higher regional groupings. For this analysis, paper brings "ideal" area which has the best values in each factor of attractiveness. These values were calculated according to examples and experiences of developed countries converted into the Slovak condition.

Tab. 1: "Ideal" area in "old" economy

\begin{tabular}{|c|c|}
\hline Factors & Values \\
\hline Transport equipment $^{3}$ & $3,25 \mathrm{~km} / 1000$ person \\
\hline Demographic structure $^{4}$ & $\begin{array}{ll} & 0-14 \text { years old }=30 \% \text { of total } \\
& 15-49 \text { years old }=50 \% \text { of total } \\
& 50+\text { years old }=20 \% \text { of total }\end{array}$ \\
\hline Educational structure $^{5}$ & $\begin{array}{ll}\text { - } & \text { primary education }=15 \% \text { of total } \\
\text { - } & \text { secondary education }=50 \% \text { of total } \\
\text { higher education }=35 \% \text { of total }\end{array}$ \\
\hline Income situation $^{6}$ & Higher than level of average wage \\
\hline Position of big city ${ }^{7}$ & Theory of central places (Christaller) \\
\hline
\end{tabular}

Created "ideal" area is usefull for comparision of region in Slovakia to make ranking of the region in terms of attractiveness. Table 2 is presenting these factors in relation to areas (NUTS 3) of Slovak republic to illustrate attractiveness of them in these terms and comparing to "ideal" one (percentage of level of "ideal" area is in the brackets next to the real value of each factor).

\footnotetext{
- Hynninen, S. - Kangasharju, A. - Pehkonen, J. (2009). Matching Inefficiencies, Regional Disparities and Unemployment.

${ }^{2}$ phenomenon of „,silver spender“ for more informatik see paper Preda, O - Negricea, C. (2007). The retail market arend the world.

${ }^{3}$ according to analysis of National Highway Company - www.ndsas.sk and Slovak Road Administration - www.cdb.sk

${ }_{5}^{4}$ according to statistics of Statistical Office of Slovak republic - www.statistics.sk, section of regional data

5 according to statistics of Statistical Office of Slovak republic - www.statistics.sk and priorities of Europe 2020

${ }^{6}$ according to statistics of Statistical Office of Slovak republic - www.statistics.sk, section of regional data

7 according to statistics of Statistical Office of Slovak republic - www.statistics.sk, section of municipal statistics
} 
Tab. 2: Attractiveness of Slovak NUTS 3 in terms of "old" economy comparing to "ideal" area

\begin{tabular}{|c|c|c|c|c|c|c|}
\hline NUTS 3 & Transport* & $\underset{* *}{\text { Demography }}$ & Education $* * *$ & $\begin{array}{c}\text { Income } \\
* * * *\end{array}$ & $\begin{array}{l}\text { Big cities } \\
* * * * *\end{array}$ & Rank \\
\hline Bratislava & $\begin{array}{c}1,287 \\
(39,6 \%)\end{array}$ & $\begin{array}{ll}. & 13(43 \%) \\
. & 52(104 \%) \\
. & 35(-75 \%) \\
\end{array}$ & $\begin{array}{ll}\text { - } & 4(27 \%) \\
- & 53(106 \%) \\
- & 43(123 \%) \\
\end{array}$ & $\begin{array}{c}132 \\
(132 \%)\end{array}$ & 9,6 & 8. \\
\hline Trnava & $\begin{array}{c}3,469 \\
(106,7 \%)\end{array}$ & $\begin{array}{ll}\text { - } & 14(46 \%) \\
\text { - } & 52(104 \%) \\
\text { - } & 34(-70 \%)\end{array}$ & $\begin{array}{ll}\text { - } & 8(53 \%) \\
\text { - } & 71(142 \%) \\
\text { - } & 21(60 \%)\end{array}$ & $\begin{array}{c}96 \\
(96 \%)\end{array}$ & 6,4 & 4. \\
\hline Trenčín & $\begin{array}{c}3,155 \\
(97,1 \%)\end{array}$ & $\begin{array}{ll}. & 13(43 \%) \\
. & 52(104 \%) \\
. & 35(-75 \%) \\
\end{array}$ & $\begin{array}{ll} & 5(33 \%) \\
. & 68(136 \%) \\
. & 27(77 \%) \\
\end{array}$ & $\begin{array}{c}91 \\
(91 \%)\end{array}$ & 6,5 & 7. \\
\hline Nitra & $\begin{array}{c}3,692 \\
(113,6 \%)\end{array}$ & $\begin{array}{ll}\text { - } & 14(46 \%) \\
\text { - } & 51(102 \%) \\
\text { - } & 35(-75 \%) \\
\end{array}$ & $\begin{array}{ll}\text { - } & 9(60 \%) \\
\text { - } & 67(134 \%) \\
\text { - } & 24(69 \%) \\
\end{array}$ & $\begin{array}{c}88 \\
(88 \%)\end{array}$ & 4,2 & 5. \\
\hline Žilina & $\begin{array}{c}2,921 \\
(89,9 \%)\end{array}$ & $\begin{array}{ll}\text {. } & 16(53 \%) \\
. & 53(106 \%) \\
. & 31(-55 \%) \\
\end{array}$ & $\begin{array}{ll}. & 6(40 \%) \\
. & 68(136 \%) \\
. & 26(74 \%) \\
\end{array}$ & $\begin{array}{c}93 \\
(93 \%)\end{array}$ & 5,7 & 6. \\
\hline $\begin{array}{l}\text { Banská } \\
\text { Bystrica }\end{array}$ & $\begin{array}{c}4,916 \\
(150,6 \%)\end{array}$ & $\begin{array}{ll}\text { - } & 15(50 \%) \\
\text { - } & 51(102 \%) \\
\text { - } & 34(-70 \%) \\
\end{array}$ & $\begin{array}{ll}\text { - } & 12(80 \%) \\
\text { - } & 64(128 \%) \\
\text { - } & 34(97 \%)\end{array}$ & $\begin{array}{c}88 \\
(88 \%)\end{array}$ & 4,7 & 1. \\
\hline Prešov & $\begin{array}{c}3,906 \\
(120,2 \%)\end{array}$ & $\begin{array}{ll}\text { - } & 19(63 \%) \\
\text { - } & 53(106 \%) \\
\text { - } & 28(-40 \%)\end{array}$ & $\begin{array}{ll}\text { - } & 14(93 \%) \\
\text { - } & 62(124 \%) \\
\text { - } & 24(69 \%)\end{array}$ & $\begin{array}{c}82 \\
(82 \%)\end{array}$ & 3,5 & 2. \\
\hline Košice & $\begin{array}{c}3,050 \\
(93,9 \%)\end{array}$ & $\begin{array}{ll} & 18(60 \%) \\
\text { - } & 52(104 \%) \\
\text { - } & 30(-50 \%)\end{array}$ & $\begin{array}{ll}\text { - } & 11(73 \%) \\
\text { - } & 63(126 \%) \\
\text { - } & 26(74 \%)\end{array}$ & $\begin{array}{c}96 \\
(96 \%)\end{array}$ & 3,9 & 3. \\
\hline
\end{tabular}

* in km per 1000 persons (year 2012)

** according to age groups, in \% of total population (year 2012)

*** three level of education, in \% of total population (year 2012)

$* * * *$ in $\%$ of average nominal wage level in Slovakia (year 2012)

$* * * * *$ in $\%$ of total cities in selected region (year 2012)

Source: own processing according to data from www.statistics.sk, www.ndsas.sk, www.cdb.sk and documents of National Council of Slovak republic and information from sites of chosen region

Regional competitive advantage in the case of the old economy revolved around the competitive advantage for firms. Our findings ${ }^{8}$ are confirmer also by the American economist and urban planner Richard Florida who noted the location decisions of firms drove regional economies, and the location decisions of people followed from the location of firms, who in turn based their decisions on natural resource endowments, transportation systems, labour costs. (Silineviča 2010, 74). According to many economists, one factor could be promoted above others - it could be said that attractiveness of area is reflected by or accounts for a large component of regional wage differentials (Beenstosck and Felsenstein 2008, 486). The rise and persistence of income disparities across regions is a major topic, however, no generalized consensus exists and the sources of these disparities is still lacking (Altomonte and Colantone 2008, 780).

\section{Environment of "new" economy}

It could be said that every economy went through certain developmental stages that highlight different sectors of the economy. We are currently witnessing a newly established trend that pushes the economy from the above mentioned levels to a new qualitatively higher level of development. The "old" industrial economy is recently overcome by creative economy.

\footnotetext{
${ }^{8}$ Results from his sub-analysis with the impact on the overall conclusions will be the content of chapter 2 . Localization of retail units
} 
Creativity is now recognized as a major factor of development. Creativity could be defined as the ability to create new knowledge and to deploy existing knowledge successfully. This idea has become popular mainly because of the American regionalists as Charles Landry and Richard Florida. Creativity has become the principal driving force in the growth and development of cities, regions and nations (Florida 2005, 11). Each place must be continually involved in a process considering the benefits and attractions to be provided to its inhabitants and the ways in which it can help them find and create new value (Angelis and Dimaki 2009, 8).

In analyzing the attractiveness of the area in terms of "new" creative economy, article provides the perception of this issue in analogy of sub-analysis of the industrial economy. Factors ${ }^{9}$ that are acting as properties increasing attractiveness of areas are for example the existence of cultural amenities, locating of universities (especially with orientation on art), openness of the area for new people but also such indicator as the expenditures on innovation. Blech also confirms this view - he argued that for a dynamic urban environment and the successful positioning as a centre of the knowledge economy the following location factors like innovation capability, knowledge and openness are of striking important (Blech 2009, 19).

Tab. 3: "Ideal" area in "new" economy

\begin{tabular}{|c|c|}
\hline Factors & Values \\
\hline Cultural amenities $^{10}$ & The highest possible number of theatres, cinemas or museums in area \\
\hline Universities $^{11}$ & The highest possible number with art orientation \\
\hline Openness of the area ${ }^{12}$ & The highest possible net inflow of people to the area \\
\hline Expenditures on innovation $^{13}$ & The highest possible number of new patents \\
\hline
\end{tabular}

Source: own processing

For this analysis, paper creates "ideal" area similarly as in terms of previous one. This is usefull for comparision of region to make ranking in terms of attractiveness for creative economy.

Tab. 4: Attractiveness of Slovak NUTS 3 in terms of "new" economy comparing to "ideal" area

\begin{tabular}{|l|c|c|c|c|c|}
\hline NUTS 3 & $\begin{array}{c}\text { Cultural amenities } \\
*\end{array}$ & $\begin{array}{c}\text { Universities } \\
* *\end{array}$ & $\begin{array}{c}\text { Openness of the area } \\
* * * *\end{array}$ & $\begin{array}{c}\text { Innovations } \\
* * * *\end{array}$ & Rank \\
\hline Bratislava & 227 & $8 / 5$ & 4374 & 242739021 & $\mathbf{1 .}$ \\
\hline Trnava & 127 & $2 / 0$ & 1238 & 33565176 & $\mathbf{4}$. \\
\hline Trenčín & 89 & $2 / 1$ & -401 & 26742202 & $\mathbf{7}$ \\
\hline Nitra & 168 & $1 / 1$ & 519 & 21298161 & $\mathbf{6 .}$ \\
\hline Žilina & 362 & $1 / 0$ & -219 & 42190618 & $\mathbf{3 .}$ \\
\hline B. Bystrica & 181 & $1 / 2$ & -652 & 26320296 & $\mathbf{5 .}$ \\
\hline Prešov & 199 & $2 / 0$ & -1062 & 13344954 & $\mathbf{8 .}$ \\
\hline Košice & 162 & $3 / 2$ & -381 & 62238926 & $\mathbf{2 .}$ \\
\hline
\end{tabular}

* number of galleries, museums, theatres, botanic gardens, zoos, ensembles, observatories (year 2012)

** number of universities / number of universities with art orientation (year 2012)

**** net migration in persons (year 2012)

**** expenditures in EURO on R\&D and the creation of new innovations (year 2012)

Source: own processing according to data from www.statistics.sk, www.culture.gov.sk, www.uips.sk,

On the basis of these studies performed on developing a ranking of regions in the view of "old" industrial economy as well as from the perspective of the "new" creative economy in terms of

\footnotetext{
${ }^{9}$ there are not so many papers about values of creative economy in relation to detail units. For more information see Iqbal, S. and Sharma, R. (2012). A Study of organization strategies, structures, culture dimensions and management kontrol systems of variol detail formats.

${ }^{10}$ according to statistics of Ministry of Culture of Slovak republic - www.culture.gov.sk

11 according to statistics of Institute of information and Prognoses of Education - www.uips.sk

12 according to statistics of Statistical Office of Slovak republic - www.statistics.sk

${ }^{13}$ according to statistics of Statistical Office of Slovak republic - www.statistics.sk
} 
Slovakia, we can now move to detection of possible correlation between the level of attractiveness of the area and the number of retail units which are localized in is selected area.

\section{Localization of retail units}

Location of retail units is one of the most important (if not the most significant) decision of managers which affects the overall functioning of the retail unit. The top lines of such units are trying to incorporate the widest possible spectrum of effects from external environment to seek their concepts. In this article, it has been defined as such influence the phenomenon of attractiveness of area.

In terms of the values of the" old" industrial economy, this paper ranks the regions of Slovakia according to their attractiveness in Table 5. Compared with the number of retail units in the region is possible to make some conclusions.

Tab. 5: Impact of attractiveness of region to number of retail units in terms of "old" economy

\begin{tabular}{|l|c|c|}
\hline NUTS 3 & Ranking of attractiveness & Number of retail units* \\
\hline Banská Bystrica & $\mathbf{1 .}$ & 1074 \\
\hline Prešov & $\mathbf{2 .}$ & 1768 \\
\hline Košice & $\mathbf{3 .}$ & 354 \\
\hline Trnava & $\mathbf{4 .}$ & 658 \\
\hline Nitra & $\mathbf{5 .}$ & 777 \\
\hline Žilina & $\mathbf{6 .}$ & 1042 \\
\hline Trenčín & $\mathbf{7 .}$ & 703 \\
\hline Bratislava & $\mathbf{8 .}$ & 4818 \\
\hline
\end{tabular}

* number of retail units (year 2012)

Source: Source: own processing according to data from www.statistics.sk

In examining the nature of the alleged correlation in this article, there is a mismatch in position of Bratislava regions and Košice regions. Extremism position of Bratislava NUTS 3 is due to localization of the capital city of Slovak republic which is the center of a strong purchasing. Regarding to Eastern Slovakia - Košice region - it has placed in top positions in terms of values of industrial economy which do not indicate also the number of retail units. The reason is the existence of the important city in the region - the metropolis of Košice - with a large number of consumers and thus retailers. On the other hand, the rest of the territory is strongly determined by the weakness of the purchasing power resulting in poor placement of referring units.

If we look at the relationship of attraction between the environment and localization of retail units in terms of "new" creative economy, Table 6 helps us to to create an image. We can see that the ranking of regions is vastly changed and the understanding of the correlation has changed too.

Tab. 6: Impact of attractiveness of region to number of retail units in terms of "new" economy

\begin{tabular}{|l|c|c|}
\hline NUTS 3 & Ranking of attractiveness & Number of retail units* \\
\hline Bratislava & $\mathbf{1 .}$ & 4818 \\
\hline Košice & $\mathbf{2 .}$ & 354 \\
\hline Žilina & $\mathbf{3 .}$ & 1042 \\
\hline Trnava & $\mathbf{4 .}$ & 658 \\
\hline Banská Bystrica & $\mathbf{5 .}$ & 1074 \\
\hline Nitra & $\mathbf{6 .}$ & 777 \\
\hline Trenčín & $\mathbf{7 .}$ & 703 \\
\hline Prešov & $\mathbf{8 .}$ & 1768 \\
\hline
\end{tabular}

* number of retail units (year 2012)

Source: Source: own processing according to data from www.statistics.sk 
It is interesting that the order of attractiveness from the point of values of creative economy reflects the reality of today's situation in the Slovak economy. It follows that this country is beginning to transform the factors of regions into so called "soft" which are based on the "new" economy and start to build the attractiveness of the areas on these values.

On the other hand, following the number of retail unit in these regions, it does not correspond with localization of retail. It is still connected to average monthly wage in the selected area (i.e. the purchasing power of the population) and other so-called "hard" factors derived from thinking of "old" industrial economy (such as population in a given area).

\section{Conclusion}

Article offers a glimpse of two types of economies - which determine the course of today's global economy - on the attractiveness of the environment and its use to attract retail units. The exploitation of factors of attractiveness are designated by values of the economy can be supported by regional policy and its effective implementation in practice as a key instrument in the hands of state, state authorities and organizations as well as regional and local self-government. There is also help and support offered to the Slovak republic by the European Union as the one of the opportunities that has not been offered to many countries that deal with similar problems with balancing of the regional disparities. (Uramová and Kožiak 2008, 6)

All in all we can conclude that according to analysis provided in this article, Slovakia is transforming its values to the picture of "new" creative economy but with still strong impact of "hard" factors which result from thinking of "old" industrial economy. Taking everything into consideration, regional attributes are the most significant determinants of selecting between range of areas. On the other hand it's important to say that - drawing on managerial implications - each individual firm would be better off locating where its particular interests and distinctive competences are. (Kottaridi and Lioukas 2011, 15)

\section{Literature}

[1] ALtOMONTE, C., COLANTONE, I. Firm heterogeneity and endogenous regional disparities. Journal of Economic Geography. 2008, 21. June 2008, 779 - 810 pp. ISSN 1468-2702.

[2] ANGELIS, V., DIMAKI, K. A Region's Basic Image as a Measure of its Attractiveness. International Journal of Economic Sciences and Applied Research. 2009, Vol. 4, No.2, 7 - 33 pp. ISSN 1791-3373.

[3] BEENSTOCK, M., FELSENSTEIN, D. Regional Heterogeneity, Conditional Convergence and Regional Inequality. Regional Studies. 2008, Vol. 42.4, May 2008, 475 - 488 pp. ISSN 13600591.

[4] BLECH, L. Growth Potentialities for Baltic Cities [online]. Frankfurt: Pricewaterhouse Coopers AG, 2009. [2013-20-04]. Available on: $<$ http://www.pwc.com/et_EE/ee/publications/assets/pwcgrowth-potentialities-for-baltic-cities.pdf $>$.

[5] EZCURRA, R., PASCUAL, P. Spatial Disparities in Productivity in Central and Eastern Europe. Eastern European Economics. 2007, Vol. 45, No.3, 5 - 32 pp. ISSN 0012-8775/2007.

[6] EZMALE, S., LITAVNIECE, L. Spatial planning as a tool for improving attractiveness of the places: Case of Latgale region. European Integration Studies. 2011, No. 05. 1-15 pp. ISSN $1822-$ 8402.

[7] FLORIDA, R. Cities and the creative class. New York: Routledge, 2008. ISBN 0-415-94887-8.

[8] NIEBUHR, A. Market Access and regional disparities - New economic geography in Europe. Springer-Verlag. 2006, Vol. 4, April 2006, 313 - 335 pp. ISSN 1865-0929.

[9] KOTTARIDI, C., LIOUKAS, S. Firm location: firm competencies, financial structure and regional determinants. Review of urban and regional development studies. 2011, Vol. 23, No. 1, 1 -21 pp. ISSN 1467-940X. 
[10] TVRDOŇ, J., HAMALOVÁ, M., ŽÁRSKA, E. Regionálny rozvoj. Bratislava: Ekonóm, 1997, ISBN 80-225-0671-0.

[11] URAMOVÁ, M., KOŽIAK, R. Regional disparities in Slovakia from the aspect of Average nominal wage. E+M Ekonomie a management. 2008. Vol. 2, 6- 19 pp. ISSN 1212-3609

This article is supported by program VEGA 1/0906/11 Corporate social responsibility in the context of strategic marketing tool in closed cycle of the food chain. 